\title{
Cholecystectomy in Sweden 2000 - 2003: a nationwide study on procedures, patient characteristics, and mortality Mats Rosenmüller ${ }^{1}$, Markku M Haapamäki ${ }^{1}$, Pär Nordin², Hans Stenlund ${ }^{3}$ and Erik Nilsson*1
}

\author{
Address: ${ }^{1}$ Department of Surgery, Umeå University Hospital, Sweden, ${ }^{2}$ Department of Surgery Östersunds Hospital, Östersund, Sweden and \\ ${ }^{3}$ Epidemiology and Public Health Sciences, Umeå International School of Public Health, Sweden \\ Email: Mats Rosenmüller - Mats.Rosenmuller@telia.com; Markku M Haapamäki - markku.haapamaki@surgery.umu.se; \\ Pär Nordin - Par.Nordin@jll.se; Hans Stenlund - hans.stenlund@epiph.umu.se; Erik Nilsson* - erik.nilsson@surgery.umu.se \\ * Corresponding author
}

Published: 17 August 2007

BMC Gastroenterology 2007, 7:35 doi:10.1 I86/147|-230X-7-35

This article is available from: http://www.biomedcentral.com/I47I-230X/7/35

(C) 2007 Rosenmüller et al; licensee BioMed Central Ltd.

This is an Open Access article distributed under the terms of the Creative Commons Attribution License (http://creativecommons.org/licenses/by/2.0), which permits unrestricted use, distribution, and reproduction in any medium, provided the original work is properly cited.
Received: 27 January 2007

Accepted: 17 August 2007

\begin{abstract}
Background: Epidemiological data on characteristics of patients undergoing open or laparoscopic cholecystectomy are limited. In this register study we examined characteristics and mortality of patients who underwent cholecystectomy during hospital stay in Sweden 2000 - 2003.

Methods: Hospital discharge and death certificate data were linked for all patients undergoing cholecystectomy in Sweden from January Ist 2000 through December 3 I $^{\text {st }} 2003$. Mortality risk was calculated as standardised mortality ratio (SMR) i.e. observed over expected deaths considering age and gender of the background population.
\end{abstract}

Results: During the four years of the study 43072 patients underwent cholecystectomy for benign biliary disease, 3II44 (72\%) using a laparoscopic technique and II928 patients (28\%) an open procedure (including conversion from laparoscopy). Patients with open cholecystectomy were older than patients with laparoscopic cholecystectomy (59 vs 49 years, $p<0.00$ I), they were more likely to have been admitted to hospital during the year preceding cholecystectomy, and they had more frequently been admitted acutely for cholecystectomy $(57 \%$ Vs $21 \%$, p $<0.00 I)$. The proportion of women was lower in the open cholecystectomy group compared to the laparoscopic group ( $57 \%$ vs $73 \%$, $p<0.001$ ). Hospital stay was 7.9 (8.9) days, mean (SD), for patients with open cholecystectomy and 2.6 (3.3) days for patients with laparoscopic cholecystectomy, $\mathrm{p}<0.00 \mathrm{I}$. SMR within 90 days of index admission was 3.89 (3.4I-4.4I) (mean and 95\% Cl), for patients with open cholecystectomy and $0.73(0.52-1.01)$ for patients with laparoscopic cholecystectomy. During this period biliary disease accounted for one third of all deaths in both groups. From 9l to 365 days after index admission, SMR for patients in the open group was I.0I (0.87-I.I6) and for patients in the laparoscopic group 0.56 (0.44-0.69).

Conclusion: Laparoscopic cholecystectomy is performed on patients having a lower mortality risk than the general Swedish population. Patients with open cholecystectomy are more sick than patients with laparoscopic cholecystectomy, and they have a mortality risk within 90 days of admission for cholecystectomy, which is four times that of the general population. Further efforts to reduce surgical trauma in open biliary surgery are motivated. 


\section{Background}

Gallstone disease is the most common of all abdominal diseases for which patients are admitted to hospital in developed countries [1] and an increase in hospital admission rates was registered in the 1990s [2] The prevalence of gallstone increases with age [3]. Hence, the safety and cost-effectiveness of treatment of gallstone disease in populations with increasing age is of great importance to public health. Cholecystectomy is the treatment of choice. The common bile duct may be cleared of gallstones at cholecystectomy or through endoscopic sphincterotomy, which involves an extra procedure [4].

Length of hospital stay for cholecystectomy became shorter during the 1980 s[5,6]. and it was demonstrated that open cholecystectomy could be performed through a smaller incision than traditionally used [7]. Small-incision or mini-laparotomy cholecystectomy was found compatible with ambulatory surgery ( 3 - 10 hrs postoperative hospital stay) [8]. However, laparoscopic cholecystectomy rapidly became the preferred technique in the early 1990s [9]. Population-based studies demonstrated great variations in cholecystectomy rates between countries before the introduction of the laparoscopic technique [5]. Thereafter, cholecystectomy rates increased in Scandinavia [10] Scotland [6], UK [3] and in the US [11]. At the end of the 1990s $70-80 \%$ of all cholecystectomies were completed as laparoscopic procedures $[6,12,13]$. , which then had also been found compatible with ambulatory surgery $[14,15]$. The shift from open to laparoscopic cholecystectomy has been accompanied by an increased incidence of iatrogenic bile duct injury [16] and an increase in the overall incidence of intra-operative injury[17].

If gallbladder surgery is to be improved we need information on patients undergoing cholecystectomy in defined populations. We have utilised data from nation-wide registers to characterise patients having open or laparoscopic cholecystectomy in Sweden, and studied mortality over the first year after admission for cholecystectomy.

\section{Methods}

Sweden (9.0 million inhabitants) has a public health-care system. The Swedish National Board of Health and Welfare's Epidemiology Centre compiles data on individual hospital discharges in the Hospital Discharge Register. Since 1987 the register has included all Swedish hospitals [18]. The record of each hospital stay contains diagnoses at discharge coded according to the Swedish version of the International Classification of Diseases, from 1997 10th revision (ICD10). Surgical procedures are classified according to the Swedish version of Classification of Surgical Procedures. All operations are classified as finally completed. This means that laparoscopic cholecystecto- mies converted to open operations are stated as open procedures in the register database. Underlying causes of death are coded by the ICD10 classification. Patients are identified through a national registration number unique for each resident in Sweden. In the file for each stay it is indicated whether the admission was elective or acute. The exact date of operation during an admission is not recorded in the Hospital Discharge Register. Hence, we have information on hospital stay but not on postoperative stay. The time at risk for death was calculated as the difference between the date of index admission and the date of death or the end of follow-up (December 31 $1^{\text {st }} 2004$ ), whichever occurred first. The patients' pre- or post-index admissions were characterised according to their primary diagnosis (biliary disease, heart-lung disease, or any other diagnosis) and by surgical procedures performed during these admissions. Procedures performed before, during, or after index stay are classified as described in the Appendix.

For all records reported to the Hospital Discharge Register a data control is run. A check is made that compulsory variables are reported, e.g. personal identification number, hospital and main diagnosis. A check is also made that codes for different variables and dates have valid values. Some obviously incorrect data are corrected in connection with the quality controls. In 2003 the main diagnosis was missing in 0.9 per cent of the hospital stays reported. For acute somatic care 0.5 per cent was missing.

\section{Patients}

All admissions from January $1^{\text {st }} 2000$ through December $31^{\text {st }} 2003$ with cholecystectomy procedure codes (JKA20, JKA21) were selected from the Hospital Discharge Register. In order to ascertain information concerning hospital admissions one year before and one year after cholecystectomy (index) admission we obtained records for all admissions from January $1^{\text {st }} 1999$ through December $31^{\text {st }}$ 2004. The study base initially comprised 44821 patients. After exclusion of patients with malignant or benign intraabdominal or kidney tumour with a procedure code for tumour resection, 44084 patients remained.

\section{Statistics}

Proportions have been compared using the chi square test or Fisher exact test when appropriate. Location of two groups of ratio scale variables were compared using independent samples t-test or Mann-Whitney U-test. A p-value less than 0.05 was considered significant.

\section{Results}

Of the 44084 patients who underwent cholecystectomy 2000 - 2003, 12675 patients (29\%) were treated by open cholecystectomy and 31409 patients (71\%) by laparoscopic cholecystectomy, see Table 1 . Acute or chronic gall- 
bladder disease (calculous or acalculous) was the indication for cholecystectomy in 41772 patients giving an incidence of 116 per 100000 inhabitants per year. Disease in the bile ducts accounted for cholecystectomy in 305 patients and acute pancreatitis in 995 patients. The group classified as "other diagnoses" comprised patients with a variety of malignant or benign diagnoses including malignancy of the upper GI-tract without tumour resection, as well as diagnoses unrelated to gallbladder disease such as appendicitis, gastritis, or ileus. Patients in this group were excluded from further analysis.

Table 2 illustrates age, gender, and mode of admission (acute/elective), and length of index (cholecystectomy) stay for patients who underwent cholecystectomy for biliary disease including acute pancreatitis 2000-2003. Mean age of patients was 59.2 year in the open group and 48.7 year in the laparoscopic group, and the percentage of women was $56.5 \%$ and $73.1 \%$, respectively. In the open group $56.6 \%$ of all patients had an acute admission compared to $20.9 \%$ in the laparoscopic group ( $<0.001$ for all analyses). Hospital stay for all patients was 4.1 (5.9) days, mean (SD). It was significantly longer for patients in the open cholecystectomy group, 7.9 (8.9) vs 2.6 (3.3) days, $\mathrm{p}<0.001$.

During the year preceding index admission, a total of 6046 of 11928 patients $(50.7 \%)$ in the open group and 12456 of 31144 patients $(40.0 \%)$ in the laparoscopic group were admitted to hospital, $\mathrm{p}<0.001$. Length of stay for heart-lung disease, for biliary disease, and for all other diagnoses was longer for patients in the open compared to patients in the laparoscopic group, see Table 3. Patients in the open group were also more likely to have undergone at least one sphincterotomy prior to cholecystectomy admission (Table 4).

Table 5 shows surgical procedures performed in addition to cholecystectomy during the index stay. Intra-operative cholangiography was performed on $72 \%$ of patients in

Table I: Primary diagnosis at index (cholecystectomy) stay, $\mathbf{n}=$ 44084

\begin{tabular}{lccccc}
\hline & \multicolumn{2}{c}{$\begin{array}{c}\text { Open } \\
\text { cholecystecto } \\
\text { my }\end{array}$} & \multicolumn{2}{c}{$\begin{array}{c}\text { Laparoscopic } \\
\text { cholecystecto }\end{array}$} & P-value* \\
& $\mathrm{n}=12675$ & \multicolumn{2}{c}{$\mathrm{n}=31409$} & \\
& $\mathrm{n}$ & $\%$ & $\mathrm{n}$ & $\%$ & \\
\hline Gallbladder disease & 11363 & 89.6 & 30409 & 96.8 & \\
Bile duct disease & 192 & 1.5 & 113 & 0.4 & \\
Acute pancreatitis & 373 & 2.9 & 622 & 2.0 & \\
Other diagnoses & 747 & 5.9 & 265 & 0.8 & $<0.001$
\end{tabular}

*calculated with the chi-square test
Table 2: Age and gender of patients; mode of admission; and length of index (cholecystectomy) stay, $n=43072$

\begin{tabular}{lccc}
\hline & $\begin{array}{c}\text { Open } \\
\text { cholecystec } \\
\text { tomy } \\
\mathrm{n}=11928\end{array}$ & $\begin{array}{c}\text { Laparoscopic } \\
\text { cholecystectomy } \\
\mathrm{n}=31144\end{array}$ & $\begin{array}{c}\mathrm{P} \text {-values } \\
*\end{array}$ \\
\hline Age, mean (SD) & $59.2(17.1)$ & $48.7(15.5)$ & $<0.001$ \\
Women (\%) & 56.5 & 73.1 & $<0.001$ \\
Acute admission No \% & 56.6 & 20.9 & $<0.001$ \\
Length of stay mean, (SD) & $7.9(8.9)$ & $2.6(3.3)$ & $<0.001$ \\
\hline
\end{tabular}

* calculated using chi-square test and t-test.

both groups. The common bile duct was explored in $17.1 \%$ of patients in the open cholecystectomy group, but only $0.8 \%$ in the laparoscopic group, $\mathrm{p}<0.001$. Laparoscopic removal of common bile duct stones through the cystic duct was used in $1.0 \%$ of patients in the open group, suggesting that these patients had undergone converted laparoscopic procedures. $1.1 \%$ of patients in the open cholecystectomy group, but only $7(0.06 \%)$ patients in the laparoscopic group, $\mathrm{p}<0.001$, underwent bilio-digestive anastomosis (creation of a shunt between the bile tree and the gastrointestinal tract). Other additional surgical procedures were also more frequent in the open cholecystectomy group.

Table 6 illustrates readmissions and length of stay per admission for biliary disease, for heart-lung disease, and for any other cause within one year of index stay. In the open group 3447 (29\%) patients were readmitted and in the laparoscopic group 5151 patients $(17 \%), \mathrm{p}<0.001$. The length of stay was longer for the open group regardless of main diagnosis. During readmission there were no significant differences between the open and the laparoscopic group with respect to sphincterotomy or rare procedures such as excision of bile duct, whereas bilio-enteric anastomosis, operation for incisional hernia, and percutaneous procedures were more frequent in the open cholecystectomy group, see Table 7 .

From Tables 4, 5, and 7 it may be deduced that $8.6 \%$ of open cholecystectomies were associated with sphincterotomy at least once as compared to 5.6\% of laparoscopic cholecystectomies. Furthermore, common bile duct exploration or transcystic stone extraction was done on $18.1 \%$ of patients in the open group and $2.7 \%$ in the laparoscopic group. Of all patients undergoing cholecystectomy, 1292 patients were admitted to hospital for sphincterotomy before the index stay and 449 after the index stay.

Table 8 shows the number of deaths and standardised mortality ratio, SMR, for patients who died within 90 days, and between 91 and 365 days after index admission. 
Table 3: Hospital admission and length of stay during one year prior to index (cholecystectomy) stay, $n=43072$.

\begin{tabular}{|c|c|c|c|c|c|c|c|}
\hline \multirow[b]{2}{*}{ Admissionst, main diagnosis } & \multicolumn{3}{|c|}{$\begin{array}{l}\text { Open cholecystectomy } \\
n=11928\end{array}$} & \multicolumn{3}{|c|}{$\begin{array}{l}\text { Laparoscopic cholecystectomy } \\
\qquad \mathrm{n}=31144\end{array}$} & \multirow[b]{2}{*}{$\mathrm{p}$-values } \\
\hline & $\begin{array}{c}\text { Admissions } \\
n\end{array}$ & $\begin{array}{l}\text { Days } \\
\text { Mean }\end{array}$ & $\begin{array}{l}\text { Days } \\
\text { (SD) }\end{array}$ & $\begin{array}{c}\text { Admissions } \\
n\end{array}$ & $\begin{array}{l}\text { Days } \\
\text { mean }\end{array}$ & $\begin{array}{l}\text { Days } \\
\text { (SD) }\end{array}$ & \\
\hline Heart-lung disease & $|45|$ & 10.5 & $(16.2)$ & 1615 & 6.2 & $(9.2)$ & $<0.001$ \\
\hline Gallbladder/bile duct disease & 3721 & 6.2 & $(7.6)$ & 8264 & 4.0 & (4.5) & $<0.001$ \\
\hline Other diagnoses & 2427 & 7.9 & $(16.1)$ & 4883 & 5.1 & $(12.8)$ & $<0.001$ \\
\hline
\end{tabular}

fone patient may have several admissions with different and/or same diagnoses.

The mortality of patients who had an open procedure was increased fourfold compared to the mortality of the corresponding general population over the three-month period after index admission. During the following nine months mortality was significantly higher than expected for patients younger than 69 years. However, for all patients in the open group SMR was $1.01(0.87-1.16)$. For patients in the laparoscopic group, SMR within 90 days was $0.73(0.52-1.01)$ and between 91 and 365 days 0.56 (0.44-0.69).

The causes of death for all patients who died within one year of cholecystectomy are shown in Table 9. In both the open and the laparoscopic group, approximately one third of all deaths within 90 days of admission could be ascribed to biliary disease. During the subsequent nine months biliary disease was a rare cause of death (6 of 185 deaths in the open group, zero of 84 deaths in the laparoscopic group).

\section{Discussion}

A decade after the introduction of laparoscopic cholecystectomy, $28 \%$ of all patients with benign biliary disease had their cholecystectomy completed as an open procedure. Patients in the open group were more likely to have an acute admission for cholecystectomy, they were ten years older than patients in the laparoscopic group, and they were more likely to have complications of gallstone disease (acute pancreatitis and common bile duct stones). They had spent more time in hospital before index admission, indicating that they were more fragile than patients in the laparoscopic group. Hospital stay at cholecystectomy was longer in the open compared to the laparoscopic cholecystectomy group. Mortality of patients in the open group was increased fourfold within three months of index admission, but close to that of the corresponding general population during the following nine months. Patients having laparoscopic cholecystectomy had a reduced mortality over the year following index admission, indicating that they were healthier than the Swedish population in general. In both cholecystectomy groups, one third of all deaths within 90 days of index admission were due to biliary causes.

Information was retrieved from a database covering all patients having inpatient cholecystectomy in Sweden 2000-2003. We lack information on cholecystectomy done as a day-case procedure, estimated to be some $13 \%$ of all cholecystectomies performed in Sweden during 2002 [19]. In population-based studies such as the present one, conversion to open cholecystectomy comprises some $10 \%$ of all laparoscopic cholecystectomies

Table 4: Interventions during one year prior to index (cholecystectomy) stay, no $=\mathbf{4 3 0 7 2}$.

\begin{tabular}{|c|c|c|c|c|c|}
\hline \multirow{2}{*}{$\begin{array}{l}\text { Interventions } \\
\text { Procedure }\end{array}$} & \multicolumn{2}{|c|}{$\begin{array}{l}\text { Open cholecystectomy } \\
\qquad \mathrm{n}=11928\end{array}$} & \multicolumn{2}{|c|}{$\begin{array}{l}\text { Laparoscopic cholecystectomy } \\
\qquad \mathrm{n}=31144\end{array}$} & \multirow[b]{2}{*}{ P-values } \\
\hline & Patients & $\%$ & Patients & $\%$ & \\
\hline Sphincterotomy & $510^{*}$ & 4.3 & $782 * *$ & 2.5 & $<0.001$ \\
\hline $\begin{array}{l}\text { Other open } \\
\text { procedures }\end{array}$ & 36 & 0.3 & 22 & 0.1 & $<0.001$ \\
\hline $\begin{array}{l}\text { Other laparoscopic } \\
\text { procedures }\end{array}$ & 4 & 0.0 & 2 & 0.0 & 0.094 \\
\hline $\begin{array}{l}\text { Other endoscopic } \\
\text { procedures }\end{array}$ & 414 & 3.5 & 497 & 1.6 & $<0.001$ \\
\hline $\begin{array}{l}\text { Percutaneous } \\
\text { procedures }\end{array}$ & 15 & 0.1 & 3 & 0.0 & $<0.001$ \\
\hline
\end{tabular}

* including 20 patients with sphincterotomy more than once

** including 15 patients with sphincterotomy more than once 
Table 5: Concomitant interventions during index (cholecystectomy) stay, $n=43072$.

\begin{tabular}{|c|c|c|c|c|c|}
\hline \multirow[b]{2}{*}{ Procedure } & \multicolumn{2}{|c|}{$\begin{array}{c}\text { Open } \\
\text { cholecystectom } \\
y \\
n=I 1928\end{array}$} & \multicolumn{2}{|c|}{$\begin{array}{c}\text { Laparoscopic } \\
\text { cholecystect } \\
\text { omy } \\
\mathrm{n}=31144\end{array}$} & \multirow[t]{2}{*}{ P-value } \\
\hline & $\mathrm{n}$ & $\%$ & $\mathrm{n}$ & $\%$ & \\
\hline $\begin{array}{l}\text { Intra-operative } \\
\text { cholangiography }\end{array}$ & 8534 & 71.5 & $\begin{array}{c}2248 \\
6\end{array}$ & 72.2 & 0.176 \\
\hline $\begin{array}{l}\text { Intra-operative } \\
\text { cholangioscopy }\end{array}$ & 1077 & 9.0 & 505 & 1.6 & $<0.001$ \\
\hline $\begin{array}{l}\text { Common bile duct } \\
\text { exploration }\end{array}$ & 2035 & 17.1 & 262 & 0.8 & $<0.001$ \\
\hline Sphincterotomy & 345 & 2.9 & 695 & 2.2 & $<0.001$ \\
\hline $\begin{array}{l}\text { Laparoscopic stone } \\
\text { extraction via cystic } \\
\text { duct }\end{array}$ & 114 & 1.0 & 581 & 1.9 & $<0.001$ \\
\hline $\begin{array}{l}\text { Bilio-enteric } \\
\text { anastomosis without } \\
\text { resection }\end{array}$ & 126 & 1.1 & 7 & 0.0 & $<0.001$ \\
\hline Excision of bile duct & 23 & 0.2 & 0 & 0.0 & $<0.001$ \\
\hline $\begin{array}{l}\text { Other operations on } \\
\text { bile duct }\end{array}$ & 20 & 0.2 & 12 & 0.0 & $<0.001$ \\
\hline $\begin{array}{l}\text { Re-intervention on } \\
\text { bile duct }\end{array}$ & 15 & 0.1 & 4 & 0.0 & $<0.001$ \\
\hline Vessel suture & 11 & 0.1 & 0 & 0.0 & $<0.001$ \\
\hline Bowel suture & 34 & 0.3 & 6 & 0.0 & $<0.001$ \\
\hline $\begin{array}{l}\text { Other open } \\
\text { procedures }\end{array}$ & 273 & 2.3 & 130 & 0.4 & $<0.001$ \\
\hline $\begin{array}{l}\text { Other laparoscopic } \\
\text { procedures }\end{array}$ & 105 & 0.9 & 79 & 0.3 & $<0.001$ \\
\hline $\begin{array}{l}\text { Other endoscopic } \\
\text { procedures }\end{array}$ & 322 & 2.7 & 579 & 1.9 & $<0.001$ \\
\hline $\begin{array}{l}\text { Percutaneous } \\
\text { procedures }\end{array}$ & 25 & 0.2 & 14 & 0.0 & $<0.001$ \\
\hline
\end{tabular}

$[12,20]$. These are classified as open cholecystectomies making it impossible to study the relative merits of open and laparoscopic cholecystectomy on an intention to treat basis. However, our study raises questions concerning cholecystectomy incidence, selection of patients for lapar- oscopic versus open cholecystectomy, and technique used for open cholecystectomy.

We observed an incidence of 116 per 100000 inhabitants per year for gallbladder disease, demonstrating that cholecystectomy rate in Sweden has prevailed at a significantly higher level than before the introduction of the laparoscopic technique [13]. There is no consensus as to which or how many patients with gallstone disease should be offered cholecystectomy. The proportion of gallstone patients having cholecystectomy varies in defined populations from 5\% to 55\% [5]. On the basis of a recent randomised controlled trial [21] it was concluded that watchful waiting may be a safe option for patients with symptomatic non-complicated gallstone disease. It has been shown that the prevalence of abdominal pain is significantly higher in cholecystectomised subjects than in subjects with a normal gallbladder [22,23]. Obviously, there is a need for further studies to gain firm evidence on which to base advice to patients with gallstones and abdominal symptoms concerning cholecystectomy.

Patients who had open cholecystectomy were older, had a higher rate of emergency admission, and a higher co-morbidity than patients with laparoscopic cholecystectomy. From three months to one year after admission for cholecystectomy standardised mortality ratio for patients in the open cholecystectomy group did not differ from that in the general population, whereas patients with laparoscopic cholecystectomy had a significantly reduced standardised mortality ration, indicating that they represent individuals which are healthier than the general population in Sweden. Within three months after admission for cholecystectomy standardised mortality ratio was increased fourfold compared to that of the general population in the open group but lower than expected for patients in the laparoscopic group. The most striking difference in standardised mortality ratio within three months after admission for cholecystectomy was seen for patients younger than 65 years, $6.84(4.84-9.39)$ for

Table 6: Readmission and hospital stay within one year of index (cholecystectomy) stay, $n=43072$

\begin{tabular}{|c|c|c|c|c|c|c|c|}
\hline \multirow[b]{2}{*}{ Readmission $\dagger$} & \multicolumn{3}{|c|}{$\begin{array}{c}\text { Open cholecystectomy } \\
n=11928\end{array}$} & \multicolumn{3}{|c|}{$\begin{array}{l}\text { Laparoscopic cholecystectomy } \\
\qquad \mathrm{n}=31 \mathrm{I} 44\end{array}$} & \multirow[t]{2}{*}{$\mathrm{p}$-values } \\
\hline & $\begin{array}{l}\text { Admissions } \\
\text { No }\end{array}$ & $\begin{array}{l}\text { Days } \\
\text { Mean }\end{array}$ & $\begin{array}{l}\text { Days } \\
\text { (SD) }\end{array}$ & $\begin{array}{l}\text { Admissions } \\
\text { No }\end{array}$ & $\begin{array}{l}\text { Days } \\
\text { Mean }\end{array}$ & $\begin{array}{l}\text { Days } \\
\text { (SD) }\end{array}$ & \\
\hline Biliary disease & 748 & 9.5 & $(17.0)$ & 848 & 5.8 & $(10.2)$ & $<0.001$ \\
\hline $\begin{array}{l}\text { Heart-lung } \\
\text { disease }\end{array}$ & 1158 & 14.3 & (23.4) & 1214 & 8.6 & $(13.4)$ & $<0.001$ \\
\hline $\begin{array}{l}\text { Other } \\
\text { diagnoses }\end{array}$ & 2246 & 10.6 & $(25.6)$ & 3699 & 7.9 & $(26.2)$ & $<0.001$ \\
\hline
\end{tabular}

fone patient may have several admissions with different and/or same diagnoses 
Table 7: Interventions during readmission within one year of index (cholecystectomy) stay, $n=43072$

\begin{tabular}{|c|c|c|c|c|c|}
\hline \multirow[b]{2}{*}{ Intervention } & \multicolumn{2}{|c|}{$\begin{array}{c}\text { Open } \\
\text { cholecystect } \\
\text { omy } \\
\mathrm{n}=11928\end{array}$} & \multicolumn{2}{|c|}{$\begin{array}{c}\text { Laparoscopic } \\
\text { cholecystect } \\
\text { omy } \\
\text { n=31144 }\end{array}$} & \multirow[t]{2}{*}{$\mathrm{P}$-values } \\
\hline & $\mathrm{n}^{*}$ & $\%$ & $\mathrm{n}^{*}$ & $\%$ & \\
\hline Sphincterotomy & 163 & 1.4 & 286 & 0.9 & 0.360 \\
\hline Excision of bile duct & 8 & 0.0 & 9 & 0.0 & 0.603 \\
\hline $\begin{array}{l}\text { Bilio-enteric } \\
\text { anastomosis without } \\
\text { resection }\end{array}$ & 18 & 0.2 & 11 & 0.0 & 0.016 \\
\hline $\begin{array}{l}\text { Other open } \\
\text { procedures }\end{array}$ & 122 & 1.0 & 75 & 0.2 & $<0.001$ \\
\hline $\begin{array}{l}\text { Other operations on } \\
\text { bile duct }\end{array}$ & 5 & 0.0 & 6 & 0.0 & 0.716 \\
\hline Incisional hernia & 97 & 0.8 & 52 & 0.2 & $<0.001$ \\
\hline $\begin{array}{l}\text { Other laparoscopic } \\
\text { procedures }\end{array}$ & 1 & .0 & 1 & 0.0 & - \\
\hline $\begin{array}{l}\text { Other endoscopic } \\
\text { procedures }\end{array}$ & 201 & 1.7 & 293 & 0.9 & 0.564 \\
\hline $\begin{array}{l}\text { Percutaneous } \\
\text { procedures }\end{array}$ & 25 & 0.2 & 5 & 0.0 & $<0.001$ \\
\hline
\end{tabular}

$*$ number of interventions in respective group

$\%$ per cent of patients in respective group

open cholecystectomy and $0.46(018-0.94)$ for laparoscopic cholecystectomy. It is not surprising that our patients with open cholecystectomy had a high standardised mortality ratio as high age, acute admission, and hos- pital admission within three months prior to cholecystectomy have been associated with increased mortality[24]. We found that one third of all patients who died within 90 days of cholecystectomy had biliary disease as the underlying cause of death, whereas this was unlikely for the rest of the postoperative year. This concurs with a study demonstrating an increased mortality up to 90 days after cholecystectomy [6] but not thereafter.

Use of cholangiography is to be recommended as it has been found to reduce the risk for common bile duct injury [25], and in the present audit intraoperative cholangiography was performed in $72 \%$ of all cholecystectomies with no difference between the open and the laparoscopic group. We found an overall incidence of endoscopic sphincterotomy (before, during, and after index admission) of $8.6 \%$ in the open cholecystectomy group compared to $5.6 \%$ in the laparoscopic group. When common bile duct exploration was indicated during cholecystectomy, it was preferably done at open cholecystectomy, $17.1 \%$ in open cholecystectomy vs $0.8 \%$ for laparoscopic cholecystectomy. An increase in endoscopic sphincterotomy in the 1990s has been noted in England [2] and in Germany[26], paralleled by a decline in common bile duct exploration. However, open bile duct surgery will always be required in a proportion of patients with common bile duct stones. The decline in training in open biliary surgery has affected junior surgeons' attitude to bile duct surgery [27], and it has increased the risk for technical complications during bile duct exploration[28]. This is a matter of concern as rare but serious complications fol-

Table 8: Deaths and standardised mortality ratio (SMR)

\begin{tabular}{|c|c|c|c|c|c|c|c|}
\hline \multicolumn{8}{|c|}{ Open cholecystectomy } \\
\hline \multicolumn{3}{|c|}{ Days after index admission } & \multicolumn{3}{|l|}{$0-90$} & \multicolumn{2}{|c|}{$91-365$} \\
\hline Age, years & Patients & Deaths & SMR & $\mathrm{Cl} 95 \%$ & Deaths & SMR & $\mathrm{Cl} 95 \%$ \\
\hline $0-64$ & 6823 & 38 & 6.84 & $4.84-9.39$ & 39 & 2.34 & $1.66-3.20$ \\
\hline $65-69$ & 1230 & 17 & 3.95 & $2.30-6.32$ & 22 & 1.70 & $1.07-2.58$ \\
\hline 70-79 & 2539 & 69 & 3.43 & $2.67-4.35$ & 56 & 0.93 & $0.70-1.21$ \\
\hline$\geq 80$ & 1336 & 114 & 3.65 & $3.01-4.38$ & 68 & 0.72 & $0.56-0.92$ \\
\hline Total & & 238 & 3.89 & $3.4 I-4.4 I$ & 185 & 1.01 & $0.87-1.16$ \\
\hline
\end{tabular}

Laparoscopic cholecystectomy

\begin{tabular}{|c|c|c|c|c|c|c|c|}
\hline \multicolumn{3}{|c|}{ Days after index admission } & \multicolumn{3}{|l|}{$0-90$} & \multicolumn{2}{|c|}{$91-365$} \\
\hline Age, years & Patients & Deaths & SMR & $\mathrm{Cl} 95 \%$ & Deaths & SMR & $\mathrm{Cl} 95 \%$ \\
\hline $0-64$ & 25822 & 7 & 0.46 & $0.18-0.94$ & 31 & 0.67 & $0.46-0.96$ \\
\hline $65-69$ & 2068 & 4 & 0.61 & $0-17-1.57$ & 16 & 0.82 & $0.47-1.33$ \\
\hline $70-79$ & $27 / 2$ & 17 & 0.91 & $0.53-1.46$ & 26 & 0.47 & $0.30-0.68$ \\
\hline$\geq 80$ & 542 & 9 & 0.90 & $0.4|-1.7|$ & 11 & 0.37 & $0.18-0.66$ \\
\hline Total & & 37 & 0.73 & $0.52-1.01$ & 84 & 0.56 & $0.44-0.69$ \\
\hline
\end{tabular}


Table 9: Cause of death.

\begin{tabular}{lcl}
\hline 0-90 days after index admission & \\
\hline Cause of death & $\begin{array}{l}\text { Open } \\
\text { cholecystectomy } n \\
=11928\end{array}$ & $\begin{array}{l}\text { Laparoscopic } \\
\text { cholecystectomy } n= \\
311144\end{array}$ \\
\hline Gallbladder disease & 74 & 9 \\
Biliary tree disease & 9 & 2 \\
Acute pancreatitis & 9 & 0 \\
Heart-lung disease & 64 & 13 \\
Other disease & 82 & 13 \\
Total & 238 & 37 \\
\hline 91 - 365 days after index admission & \\
\hline Cause of death & Open & \\
& cholecystectomy & cholecystectomy \\
\hline Gallbladder disease & 2 & 0 \\
Biliary tree disease & 2 & 0 \\
Acute pancreatitis & 2 & 0 \\
Heart-lung disease & 43 & 27 \\
Other diagnoses & 136 & 84 \\
Total & 185 & \\
\hline
\end{tabular}

lowing endoscopic sphincterotomy are well-known [29]. In a long-term follow-up after endoscopic sphincterotomy, early complications were seen in $16 \%$ of patients and late complications in $24 \%$ of patients [30].

In view of the excess mortality in open cholecystectomy seen in this study it is appropriate to consider the use of small-incision cholecystectomy, which according to a Cochrane review [31] is preferable to open cholecystectomy if expertise is available. Systematic reviews have also shown that laparoscopic cholecystectomy and small-incision cholecystectomy should be regarded as equal with respect to postoperative recovery and complication, although small-incision cholecystectomy is associated with a shorter operating time $[5,32]$. Further, the longterm cosmetic effects of laparoscopic and small-incision open cholecystectomy do not differ significantly [33]. However, data from a Swedish national quality register [34] for gallbladder surgery indicate that small-incision cholecystectomy was used for less than five per cent of cholecystectomies in Sweden 2006.

\section{Conclusion}

We have demonstrated that open cholecystectomy, the most traumatic of cholecystectomy methods used today, has been preferred for our most vulnerable patients, either as primary procedure or as conversion from laparoscopic cholecystectomy. There is an obvious need for further studies of techniques used in gallbladder surgery. This is of particular importance in populations with increasing
Table 10 : Operations classified for the present study

\begin{tabular}{|c|c|}
\hline \multicolumn{2}{|l|}{ Cholecystectomy-related procedures (JKA20, JKA2 I excluded) } \\
\hline Intraoperative cholangiography & TJK00, TJKOI \\
\hline Intraoperativ cholangioscopy & JKB20, TJK2I \\
\hline Common bile duct exploration & JKBO0, JKBOI \\
\hline Laparoscopic transcystic stone removal & JKBII \\
\hline Bilio-enteric anastomosis without resection & JKD \\
\hline Endoscopic sphincterotomy & JKE02 \\
\hline Excision of bile duct & $\mathrm{JKC}$ \\
\hline Reintervention on bile duct & $\mathrm{JKF}$ \\
\hline Vessel suture & $\mathrm{PCB}, \mathrm{PCC}$ \\
\hline Bowel suture & JFA70, JFA7I \\
\hline $\begin{array}{l}\text { Reoperations due to complications after previous } \\
\text { abdominal surgery }\end{array}$ & JW \\
\hline \multicolumn{2}{|l|}{ Other open procedures } \\
\hline Cholecystotomy & JKA00 \\
\hline Cholecystostomy & JKAIO \\
\hline Other operation on gallbladder & JKA96 \\
\hline Bile duct suture & JKB40 \\
\hline Other local operation on bile duct & JKB96 \\
\hline Transduodenal sphincterotomy & JKEOO \\
\hline Transduodenal sphincteroplasty & JKE06 \\
\hline $\begin{array}{l}\text { Other transduodenal procedure on bile duct or } \\
\text { sphincter }\end{array}$ & JKE96 \\
\hline Other operation on bile duct & JKW96 \\
\hline Incisional hernia repair & JAD \\
\hline \multicolumn{2}{|l|}{ Other laparoscopic procedures } \\
\hline Laparoscopic cholecystostomy & JKAII \\
\hline Other laparoscopic procedure on gallbladder & JKA97 \\
\hline Other laparoscopic local operation on bile duct & JKB97 \\
\hline Other laparoscopic operation on bile duct & JKW97 \\
\hline \multicolumn{2}{|l|}{ Other endoscopic procedures } \\
\hline Removal of common bile duct stones & JKEI2 \\
\hline Lithotripsy & JKEI5 \\
\hline Internal drainage & JKEI8 \\
\hline Removal of foreign body (stent) & JKE22 \\
\hline External drainage & JKE25 \\
\hline Dilatation of bile duct & JKE32 \\
\hline Other endoscopic procedure & $\begin{array}{l}\text { JKE98, } \\
\text { JKW98 }\end{array}$ \\
\hline \multicolumn{2}{|l|}{ Percutaneous procedures } \\
\hline Cholecystostomy & JKAI3 \\
\hline Transhepatic drainage & $\mathrm{JKB} 30$ \\
\hline
\end{tabular}

age [35]. Future studies in this field have to recognise the substantial learning curve necessary to master the "videoeye-hand" coordination involved in the laparoscopic technique[17] and they should have a cost-utility approach.

\section{Competing interests}

The author(s) declare that they have no competing interests. 


\section{Authors' contributions}

MR, MH, PN, HS, and EN designed the study; HS performed the statistical analyses; EN drafted the manuscript. All authors have contributed to, read, and approved the final version of the manuscript.

\section{Appendix}

See Table 10

\section{Acknowledgements}

The study was financially supported by the County Councils of Northern Sweden (Norrlandstingens Regionförbund). The funding body had no influence on study design; in the collection, analysis, and interpretation of data; in the writing of the manuscript; and in the decision to submit the manuscript for publication.

Approval was obtained from the Regional Ethics Committee of Umeå, Sweden. Dnr 06-027M.

\section{References}

I. Beckingham IJ: ABC of diseases of liver, pancreas, and biliary system. Gallstone disease. BMJ 200I, 322:9I-94.

2. Kang JY, Ellis C, Majeed A, Hoare J, Tinto A, Williamson RCN, Tibbs C], Maxwell JD: Gallstone - an increasing problem: a study of hospital admissions in England between 1989//990 and I999/ 2000. Aliment Pharmacol Ther 2003, 17:561-569.

3. Aerts $R$, Penninckx $F$ : The burden of gallstone disease in Europe. Aliment Pharmacol Ther 2003, 18 (Suppl 3):49-53.

4. Martin DJ, Vernon DR, Toouli J: Surgical versus endoscopic treatment of bile duct stones (Review). The Cochrane Database of Systematic Reviews 2006:CD003327.

5. Jorgensen T: Treatment of gallstone patients. Copenhagen , National Institute of Public Health, Denmark, and Danish Institute for Health Technology Assessment; 2000.

6. McMahon AJ, Fischbacher CM, Frame SH, MacLeod CM: Impact of laparoscopic cholecystectomy: a population-based study. The Lancet 2000, 356:1632-1637.

7. Dubois F, Berthelot B: Cholecystectomie par mini-laparotomie. Nouvelle Presse Medicale 1982, I I: | |39-| | 4 |.

8. Ledet WP Jr.: Ambulatory cholecystectomy without disability. Arch Surg 1990, 125: | 434-1435.

9. NIH Consensus conference. Gallstones and laparoscopic cholecystectomy. JAMA 1993, 269:1018-1024.

10. Mjåland O, Adamsen S, Hjelmqvist B, Ovaska J, Buanes T: Cholecystectomy rates, gallstone prevalence, and handling of bile duct injuries in Scandinavia. Surgical Endoscopy 1998, | 2:1386-1389.

II. Steiner CA, Bass EB, Talamini MA, Pitt HA, Steinberg EP: Surgical rates and operative mortality for open and laparoscopic cholecystectomy in Maryland. The New England Journal of Medicine 1994, 330:403-408.

12. Livingston $\mathrm{EH}, \mathrm{Rege} \mathrm{RV}$ : A nationwide study of conversion from laparoscopic to open cholecystectomy. American Journal of Surgergy 2004, I 88:205-2।I.

13. Nilsson E, Fored M, Granath F, Blomquist P: Cholecystectomy in Sweden 1987-1 999. A nationwide study of mortality and preoperative admissions. Scandinavican Journal of Gastroenterology 2005, 40: I 478-| 485.

14. Leeder PC, Mattews T, Krzeminska K, Dehn TCB: Routine daycase laparoscopic cholecystectomy. British Journal of Surgery 2004, $91: 312-316$

15. Calland JF, Tanaka K, Foley E, Bovbjerg VE, Markey DW, Blome S, Minasi JS, Hanks JB, Moore MM, Young JS, Jones RS, Schirmer BD, Adams RD: Outpatient laparoscopic cholecystectomy: Patient outcomes after implementation of a clinical path way. Ann Surg 200I, 233:704-7I5.

16. Connor S, Garden OJ: Bile duct injury in the era of laparoscopic cholecystectomy. British Journal of Surgery 2006, 93:158-168.

17. Hobbs MS, Mai Q, Knuiman MW, Fletcher DR, Ridout SC: Surgeon experience and trends in intraoperative complications in laparoscopic cholecystectomy. British Journal of Surgery 2006, 93:844-853

18. [http://www.socialstyrelsen.se/en/statistics/statsbysubject/ The+Swedish+Hospital+Discharge+Register.htm]

19. Leo J, Filipovic G, Krementsova J, Norblad R, Söderholm M, Nilsson $E$ : Open cholecystectomy in the era of laparoscopic cholecystectomy - a prospective cohort study. BMC Surgery 2006, 6:5.

20. Ishizaki Y, Miwa K, Yoshimoto J, Sugo H, Kawasaki S: Conversion of elective laparoscopic to open cholecystectomy between 1993 and 2004. British Journal of Surgery 2006, 93:987-99I.

21. Vetrhus M, Soreide O, Solhaug JH, Nesvik I, Sondenaa K: Symptomatic, non-complicated gallbladder stone disease. Operation or observation? A randomized clinical study. Scandinavican Journal of Gastroenterology 2002, 37:834-839.

22. Jorgensen T: Abdominal symptoms and gallstone disease: an epidemiological investigation. Hepatology 1989, 9:856-860.

23. Borch K, Jönsson K, Zdolsek JM, Halldestam I, Kullman E: Prevalence of gallstone disease in a Swedish population sample. Scandinavican Journal of Gastroenterology 1998, 33:1219-1225

24. Bredesen J, Jorgensen T, Andersen TF, Brönnum-Hansen H, Roepstorff C, Madsen M, Wille-Jorgensen P, Loft A: Early postoperativ mortality following cholecystectomy in the entire female population of Denmark, 1977-1981. World Journal of Surgery 1992, 16:530-535.

25. Flum DR, Dellinger P, Chan L, Koepsell T: Intraoperative cholangiography and risk of common bile duct injury during cholecystectomy. JAMA 2003, 289:1639-1644.

26. Hüttl TP, Hrdina C, Geiger TK, Meyer G, Schildberg FW, Krämling $\mathrm{HJ}$ : Management of common bile duct stones - Results of a nationwide survey with analysis of $8 \mathbf{4 3 3}$ common bile duct explorations in Germany. Zentralblatt für Chirurgie 2002, 1 27:282-288.

27. Chung RS, Wojtasik L, Pham Q, Chari V, Chen P: The decline of training in open biliary surgery. Effect on the recidents' attitude towards bile duct surgery. Surgical Endoscopy 2002, I 7:338-340.

28. Livingston EH, Rege RV: Technical complications are rising as common duct exploration is becoming rare. Journal of the American College of Surgeons 2005, 201:426-433.

29. Freeman ML, Nelson DB, Sherman S, Haber GB, Herman ME, Dorsher PJ, Moore JP, Fennerty B, Ryan ME, Shaw MJ, Lande JD, Pheley AM: Complications of endoscopic biliary sphicterotomy. The New England Journal of Medicine 1996, 335:909-918.

30. Bergman JJGHM, van der Mey S, Rauws EAJ, Tijssen JGP, Gouma DJ, Tytgat GN], Huibregtse K: Long-term follow-up after endoscopic sphincterotomy for bile duct stones in patients younger than 60 years of age. Gastrointest Endosc 1996, 44:643-649.

3I. Keus F, dejong JAF, Gooszen HG, van Laarhoven CJHM: Small-incision versus open cholecystectomy for patients with symptomatic cholecystolithiasis (Review). The Cochrane Database of Systematic Reviews 2006:CD004788.

32. Keus F, delong JAF, Gooszen HG, van Laarhoven CJHM: Laparoscopic versus small-incision cholecystectomy for patients with symptomatic cholecystolithiasis (Review). The Cochrane Database of Systematic Reviews 2006:CD006229.

33. Ros A, Nilsson E: Abdominal pain and patient overall and cosmetic satisfaction one year after cholecystectomy. Outcome of a randomised trial comparing laparoscopic and minilaparotomy choleycystectomy. Scandinavian journal of gastroenterology 2004, 39:773-777.

34. [http://www.ucr.uu.se/gallriks/].

35. Etzioni DA, Liu JH, Maggard MA, Ko S: The aging population and its impact on the surgery workforce. Ann Surg 2003, 238: $170-177$.

\section{Pre-publication history}

The pre-publication history for this paper can be accessed here:

\section{http://www.biomedcentral.com/1471-230X/7/35/pre} pub 